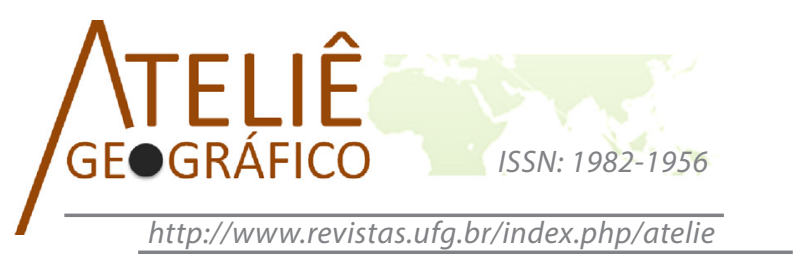

\title{
A Segregação racial em Goiânia: representação dos dados de cor ou raça (IBGE, 2010)
}

\author{
Racial segregation in Goiania, go, brazil: data \\ representation of race or color (IBGE, 2010)
}

\section{La Segregación racial em Goiânia: representación de los datos de color o raza (IBGE, 2010)}

\author{
Danilo Cardoso Ferreira \\ Universidade Estadual de Campinas \\ prof.daniloueg@gmail.com
}

\author{
Alex Ratts \\ Universidade Federal de Goiás \\ alex.ratts@uol.com.br
}

\begin{abstract}
Resumo
O presente trabalho consiste em uma abordagem geográfica e uma representação cartográfica dos processos de segregação e de diferenciação socioespacial combinados com a dimensão racial, em Goiânia, com base nos dados de cor/ raça e renda do Censo Demográfico (IBGE, 2010). Em primeiro lugar, trazemos leituras do campo da Geografia das relações raciais na sociedade brasileira, voltadas para o espaço urbano, com foco nos referidos processos. Em seguida, tratamos da construção de uma cartografia racial e das questões metodológicas da pesquisa. Discutimos vários estudos realizados acerca da segregação social na capital goiana e elaboramos vários mapas de "espaços de maioria branca" e "espaços de maioria negra", associados com a identificação de cor ou raça e os níveis de classe, distribuídos por bairros da cidade. Por fim concluímos que os processos em pauta têm uma estreita correlação com a diferença e com a desigualdade racial na cidade, fenômeno que acontece em outras metrópoles brasileiras.

Palavras-chave: Diferenciação socioespacial, Segregação socioespacial, Relações raciais, Cartografia racial.
\end{abstract}




\begin{abstract}
This paper consists of a geographical approach and a cartographic representation of the processes of segregation and socio-spatial differentiation combined with the racial dimension in Goiania based on color data / race and income of the Census Brazilian Institute of Geography and Statistics (IBGE, 2010). At first, we bring readings from the field of Geography of race relations in Brazilian society, facing urban space, focusing on those cases. Then we discuss about the construction of a racial mapping and methodological research questions. We brought several studies on the social segregation in Goias and prepared capital several maps of "mostly white spaces" and "spaces of black majority", associated with the identification of color or race and class levels spread across city neighborhoods. Finally we conclude that the processes under discussion have a close correlation with the difference and the racial inequality in the city, a phenomenon that happens in other Brazilian cities. Keywords: socio-spatial differentiation, socio-spatial segregation, race relations, racial cartography.
\end{abstract}

\begin{abstract}
Resumen
El presente trabajo consiste en un enfoque geográfico y una representación cartográfica de los procesos de segregación y de diferenciación socioespacial combinados con la dimensión racial, en Goiânia, basado en datos de color/raza y renta del Censo Demográfico (IBGE, 2010).En primer lugar, traemos lecturas del campo de la Geografía de las relaciones raciales en la sociedad brasileña, direccionadas para el espacio urbano, con foco en los referidos procesos. En seguida, tratamos de la construcción de una cartografía racial y de las cuestiones metodológicas de investigación. Discutimos varios estudios realizados sobre la segregación social en la capital goiana y elaboramos varios mapas de "espacios de mayoría blanca" y "espacios de mayoría negra", asociados con la identificación de color o raza y a los niveles de clase, repartidos por barrios de la ciudad. Por fin llegamos a la conclusión que los procesos en pauta tiene una estrecha correlación con la diferencia y con la desigualdad racial en la ciudad, fenómeno que ocurre en otras metrópolis brasileñas.

Palabras-Claves: Diferenciación, socioespacial, Segregación, Relaciones raciales, Cartografía racial.
\end{abstract}

\title{
Introdução
}

O desenvolvimento de pesquisas sobre estudos urbanos e sua relação com a população entendida em termos raciais, é cada vez maior, gerando diversos indicadores, como os de exclusão e inclusão social e outros dados de cor/raça ${ }^{1}$ interseccionados com renda. Esses permitem traçar diversas relações e trazem como resposta maior conhecimento sobre a realidade. Porém, somente os índices não dariam informações claras e diretas sobre a realidade. A disposição desses dados em forma espacial, por meio dos Sistemas de Informação Geográfica (SIG), permite entender a sua relação e distribuição na área urbana.

1. Para o tratamento dos dados de cor ou raça foi utilizado o mesmo critério de Telles (2003), Paixão (2013) e Garcia (2006) para a classificação. Isto significa dizer que tratamos as seguintes variáveis de cor ou raça; "branco", "negro" (o somatório de "pretos" + "pardos"), "indígenas" e "amarelos". Portanto, não foi mantida a classificação do IBGE (2010) que identifica por cor ou raça os seguintes grupos: "brancos", "pretos", "pardos", "amarelos" e "indígenas". 
Os bancos de dados georreferenciados fornecem informações imprescindíveis sobre as diferenças internas do país, dos estados e das cidades. Os sistemas de informação geográfica apresentam, portanto, enorme potencial para definir estratégias políticas "globais" e "locais" para os estudos urbanos. Nesse sentido, optamos por trabalhar com os dados georreferenciados de cor e raça, renda e outros disponibilizados pelo Instituto Brasileiro de Geografia e Estatística (IBGE) relativos ao Censo Demográfico (2010).

Vários estudos que partem da análise da distribuição de diversos dados espaciais (sociais e físicos), na cidade, evidenciam a existência da segregação residencial urbana, processo que corresponde à "separação espacial de diferentes grupos" - principalmente raciais e sociais que vivem na cidade (VILLAÇA, 2001).

O lugar social, no espaço urbano, que o negro ocupa não é o mesmo do branco. A separação nem sempre é evidente, pois há um permanente controle, em discursos de igualdade, para que possa parecer que todos têm o mesmo tipo de acesso à cidadania. Por isso, a importância de se pensar a segregação urbana analisando a sua dialética social e racial. A pergunta que se faz, então, é se existe uma relação da segregação urbana, residencial e econômica, como apresentada nos estudos sobre as cidades, com a variável raça. A partir dessa associação, chegaremos à compreensão contextualizada não somente da cidade pela espacialização dos níveis de renda, mas também pela dimensão racial.

A segregação além de ser uma dinâmica de separação de alguns grupos subalternizados, se desdobra no processo de autossegregação correlacionado ao mercado imobiliário que separa uma parte das "classes médias e altas" do restante da sociedade, privando muitos(as) do "direito à cidade", influenciando, assim, os conflitos de classes e outras disputas econômicas e raciais, "mais ou menos" manifestas.

Goiânia é considerada uma cidade nova que pode ser comparada a outras capitais brasileiras e mesmo assim reproduz o processo de segregação, a exemplo de capitais como Rio de Janeiro e São Paulo. O importante a se destacar é que esse processo é produzido pela própria reprodução do capital juntamente com intervenções e auxílio do Estado. Nas capitais citadas, essa realidade é bem presente como no Rio de Janeiro, com muitos aglomerados subnormais em comunidades, cortiços em péssimas condições de vida, exemplos de construções em áreas de risco, com baixa infraestrutura urbana.

Diante das leituras e da observação da cidade, algumas questões nos deixaram inquietos. O conceito de segregação residencial, social e econômica é capaz de explicar a dinâmica socioespacial e racial da produção do espaço urbano? Há uma segregação econômica, residencial e racial em Goiânia? Como ela se espacializa? Por que os espaços residenciais com maiores aglomerações de ricos em Goiânia correspondem a uma maioria de "brancos"? Por que certos espaços sociais têm pouca presença negra?

Nosso pressuposto é que, em face da formação étnico-racial e social do Brasil, a segregação, além de ser um dos processos espaciais urbanos capitalistas, se correlaciona aos espaços mais ou menos demarcados pelas relações raciais entre "brancos" e "negros", influenciando a vida na cidade, sobretudo o exercício do direito.

Pesquisas feitas por Telles (2003), França (2010), Paixão (2013), Garcia (2006), Campos (2006), Rios Neto e Riani (2009), apresentam evidências e reflexões acerca do 
processo de segregação residencial, associada à análise racial. Nesses casos, uma não exclui a outra, como se pode ver nos estudos desses(as) sociólogos(as), demógrafos(as), ou geógrafos(as) para algumas cidades brasileiras que são consideradas metrópoles.

Como apontado por Santos, R. um dos objetivos do trabalho também tem como foco "utilizar o espaço urbano como chave de compreensão do racismo" e compreender a "luta contra o racismo através da discussão sobre as manifestações deste sistema de dominação no espaço urbano" (2012, p. 28).

\section{Cartografia da segregação socioespacial e racial em Goiânia}

O espaço urbano das cidades brasileiras é composto por processos de diferenciações e segregações socioespaciais. As diferenciações se expressam no contexto social, os quais se evidenciam em espaços de riqueza e pobreza bastante próximos fisicamente, em distâncias sociais que se correlacionam com outras barreiras e enclaves, como os de ordem racial. A segregação se constitui como separações mais diretas e impactantes. Estudos feitos sobre segregação, em Goiânia, tratam esse processo como sendo resultado da produção do crescimento urbano, regulada pelo capital, sem associar a variável racial ${ }^{2}$.

$\mathrm{Na}$ escala do corpo, do indivíduo, pode-se observar o pertencimento racial e a maior ou menor presença dos grupos raciais no espaço urbano. É o indivíduo, em sua residência, que responde ao questionário do IBGE e que pode ser considerado sujeito dos processos espaciais, ainda que visto sob o plano das estatísticas. De um lado, é ele(a) que se expressa e auto se identifica como segmento étnico-racial, informando escolaridade, renda e domicílio. De outro, tendo em mente os dados do censo, podemos inferir os processos de segregação socioespacial em Goiânia a partir do local, do bairro de residência e da condição social.

A exemplo de outras grandes cidades, Goiânia apresenta distintos "padrões de ocupação e intensidade urbana" (SOUZA, 2013) que produzem a diferenciação no espaço urbano, visíveis na paisagem da capital, como espaços de centralidades financiados pelo capital imobiliário e empresas privadas e outros espaços segregados - Vila Lobó, Vietnã, Jardim Curitiba, Madre Germana I, Tremendão, Finsocial, Vale dos Sonhos I e II - com condições de vida precárias, com limitações no direito à cidade e à vida na metrópole.

Adiferenciação socioespacial passa pela paisagem urbana, pelos distintos padrões de formação da cidade, pelo uso do espaço urbano, condicionado pelo próprio Estado, associado às atividades do capital. A segregação passa pela separação dos indivíduos e segmentos populacionais com base na condição social (classe ou renda), o que limita o direito à cidade e passa também pelas diferenças raciais. Ambas se combinam.

Os dois conceitos - diferenciação socioespacial e segregação socioespacial podem ser aplicados à realidade de Goiânia. A diferenciação se apresenta por meio de seus contrastes sociais em espaços de riqueza e pobreza, e das diferenças étnico-raciais que se reproduzem e coexistem na organização e produção do espaço urbano. A segregação

2. Conferir, dentre outros: (MOYSÉS \& BERNARDES, 2003; MOYSÉS, 2005). 
urbana está associada à diferenciação, mas se reelabora em separações que, na sociedade brasileira, multiétnica e plurirracial, passam também pela identificação ou pertencimento a esses segmentos. Percebe-se que existe uma combinação da condição social e de cor/ raça para entender essas dinâmicas, o que se evidencia, como veremos pela concentração de grupos brancos, vivendo em bairros (Setor Oeste, Setor Bueno, Jardim Goiás, Setor Sul) centrais e pela concentração de grupos negros em bairros periféricos de Goiânia.

Moyses et., al (2007) discutem o processo de formação e ocupação de Goiânia a partir da organização e produção da lógica capitalista do espaço urbano. Relacionando, consequentemente, a segregação a um retrato e reflexo dessa produção. Os autores também evidenciam que a capital goiana é uma cidade desigual, principalmente no que se refere à concentração de renda e esse processo conduz a diversos conflitos em áreas que são almejadas pelo mercado imobiliário, como afirma os autores:

A história urbana de Goiânia está marcada por conflitos de interesses e as alianças estabelecidas entre eles nem sempre consideram a ideia histórica de que a cidade é conhecida e reconhecida como uma cidade planejada. O fato é que o desenho urbano da cidade conforma e expressa os interesses em conflitos. De um lado o capital imobiliário impõe seus projetos, desenha e redesenha espaços que até então pareciam consolidados, cria e recria novas centralidades; de outro, os movimentos de luta pela casa própria também se projetam sobre a cidade, e deixam uma aparência de que também são atores que reordenam o espaço urbano. Na verdade, na correlação de forças, estes perdem mais do que ganham, não conseguem ter direito à cidade e acabam se localizando nas áreas menos urbanizadas que o capital, temporariamente, permite. (2007, p. 37).

Goiânia, uma importante capital com influência na região Centro-Oeste do país, em face de seu crescimento e metropolização, se coloca entre outras cidades brasileiras que se transformam constantemente com o processo de urbanização das últimas décadas do século XX e com as primeiras do século atual (ARRAIS, 2013). É importante destacar neste ponto que o crescimento urbano e o processo de metropolização de Goiânia tem uma forte ligação com a modernização territorial do Estado de Goiás (CASTILHO, 2016). Apesar de ser inicialmente uma capital planejada na década de 1930, a cidade apresenta diversos problemas com relação às distinções espaciais, tornando-se um desafio pensar no processo de desigualdade social.

Como apontam os estudos sobre urbanização no Brasil no início da década de 60 até o fim dos anos 90 , do século $\mathrm{XX}$, as grandes cidades brasileiras triplicaram o número de habitantes, o que mudou toda a sua dinâmica (SANTOS, M. 2006), reproduzindo espacialmente a segregação e as desigualdades sociais. A distribuição desigual da infraestrutura urbana pelo estado, somada à ação do mercado imobiliário, proporciona e influencia diversos conflitos urbanos, principalmente entre segmentos de classe, por vezes em posições extremas.

Cabe ressaltar que há um crescente processo de conurbação entre os municípios vizinhos, sobretudo com Aparecida de Goiânia, o que contribui para intensificar problemas sociais, assim como apresenta Arrais (2013). É importante destacar que 2.173.141 da população (37\%) do Estado de Goiás, segundo o IBGE (2010), vivem na região metropolitana de Goiânia. 
Voltando a Moysés e Bernardes (2003), destacamos que houve muitas ocupações em áreas públicas que estudiosos e a mídia denominam de "invasões":

A invasão de áreas públicas na capital não é um fenômeno recente. Esse fenômeno remonta a criação de Goiânia. Os que foram chegando aos poucos, dispersamente, sozinhos ou com suas famílias, sem prévio contrato de trabalho, agrupavam-se a população, já residente às margens direita do Córrego Botafogo. Essa região composta pela margem direita do córrego Botafogo ia se adensando a medida que novas moradias iam sendo construídas, formando os bairros operários periféricos ao "Plano Urbanístico de Goiânia". Somaram se outras regiões posteriormente: Areião, Vila Nova, invasões milionárias, a exemplo da rua 115, no Setor sul (área, que era um parque linear, foi doada à legião do Bem-Estar Social, entidade beneficente, já extinta, que acabou negociando os terrenos). Jardim Nova Esperança; Vila Curitiba, Finsocial; Bairro da Vitória e suas sete etapas, o Bairro São Carlos e o loteamento da Fazenda São Domingos; Dom Fernando 1 e 2 e o Jardim Conquista. (MOYSÉS, BERNARDES, 2003, p. 16)

Dos bairros destacados pelos autores, Areião e Vila Nova eram espaços de grupos de "classe média baixa" que se transformaram com o desenvolvimento do mercado imobiliário, de onde decorreu sua valorização econômica (MOYSÉS, BERNARDES, 2003). Os bairros da região noroeste Jardim Nova Esperança, Vila Curitiba, Finsocial, Jardim da Vitória são espaços segregados de "operários", consoante ao que destacam Moysés e Bernardes (2003). Essas áreas sofrem com os deslocamentos do transporte público, com ruas que ainda não possuem massa asfáltica e saneamento básico. Para os autores, são espaços “excluídos” de Goiânia.

A Figura 1 mostra como a cidade de Goiânia cresceu nas três últimas décadas se periferizando com áreas pobres e condomínios fechados, assim como outras metrópoles brasileiras.

A figura apresenta certo crescimento nas regiões Norte, Leste, Oeste e Sudoeste, principalmente para a região Norte em função dos migrantes que chegaram a Goiânia nas últimas décadas, populações de "classe baixa", segundo apresentam Martins (2014) e Moysés (2009). Hoje, a região Oeste é local de implantação de projetos habitacionais do Governo, o Programa Minha Casa Minha Vida. Exemplo: Bairro, Jardins do Cerrados I ao XII, para a "classe extremamente pobre e classe baixa", influenciando ainda mais os padrões de segregação dos sujeitos na cidade. As regiões Leste e Sudoeste também estão marcadas pelo crescimento dos condomínios fechados de acordo com os estudos de Moysés et al,. (2007) e Martins (2014).

Uma das principais questões, que advém das leituras, é que a segregação residencial, no caso de Goiânia, se dá pela separação, por vezes conflituosa, de segmentos residentes em bairros e/ou condomínios de "classe média alta" em relação a populações que não possuem condições econômica e social para ter "direito à cidade":

A convivência entre esses espaços segregados e os outros espaços sociais da cidade de Goiânia nem sempre é pacífica, configurando uma relação demarcada pelo estranhamento, pela rejeição. A violência delimita as novas fronteiras das 


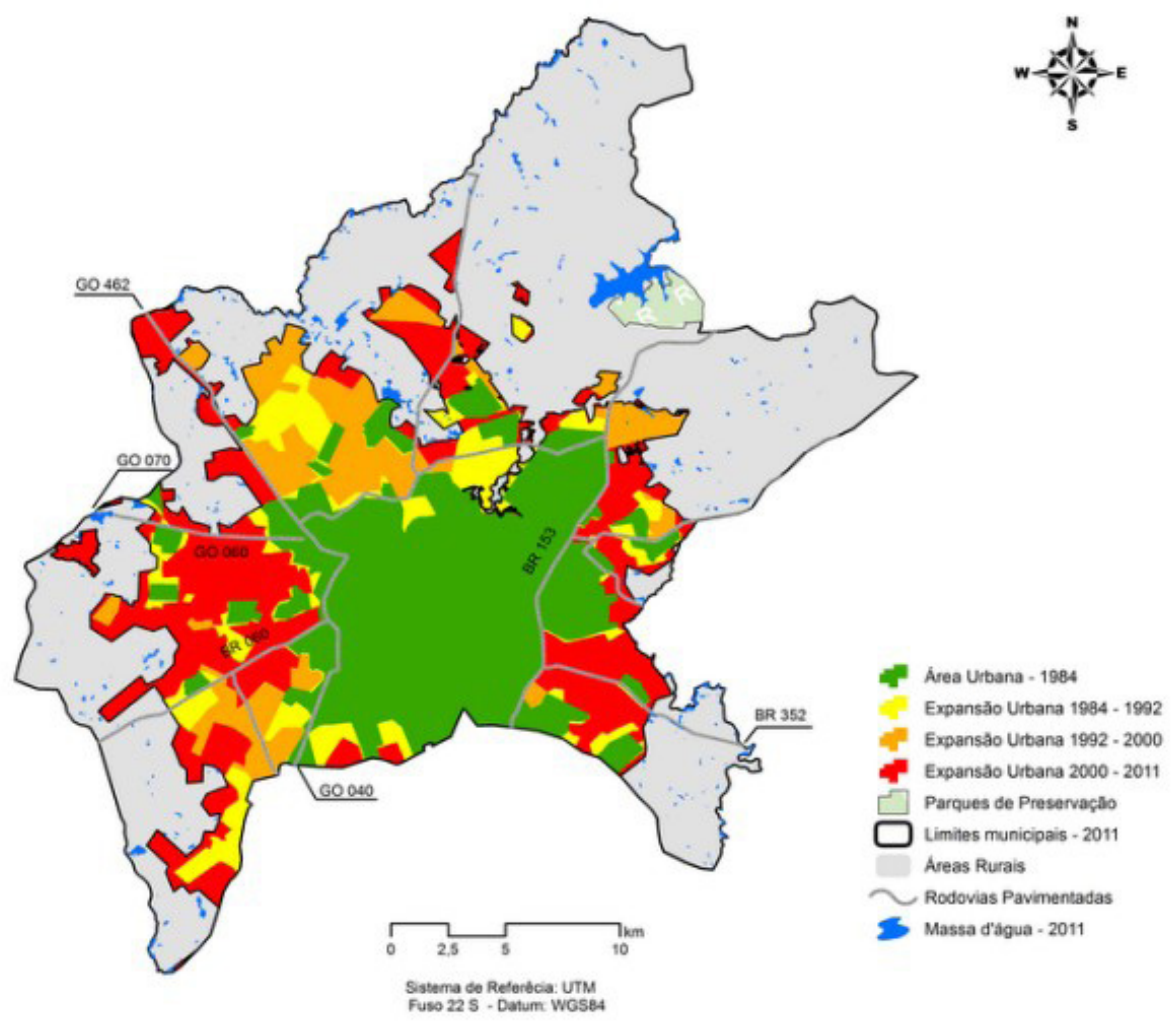

Figura 1. Crescimento urbano de Goiânia de 1984 a 2011.

cidades através de manifestações explícitas de tensões urbanas, resultantes dos embates dramáticos entre cidadania, exclusão social e segregação urbana. Espaços segregados por condições de ocupação, renda, escolaridade, e outros indicadores sociais. Espaços que carregam signos demarcadores de confinamento doméstico: muralhas, arames farpados, cercas elétricas, sistemas sofisticados de alarmes, sensores e câmeras de vídeo. Essas marcas não se restringem aos "condomínios horizontais fechados", pois se difundem pelas cidades nas habitações isoladas e em edifícios de apartamentos de bairros de classe médias e altas de Goiânia. (MOYSÉS e BERNARDES, 2003, p. 18)

O estudo de Moysés e Bernardes, para a região noroeste de Goiânia, mostra que essa parte da cidade "está formada por um conjunto de loteamentos clandestinos, não legalizados” (2005, p.15), que contribuem para pensar no processo de segregação na capital goiana, pois são populações que estão em áreas impróprias que inviabilizam parte do processo de urbanização.

Ainda acerca do processo de organização socioespacial em Goiânia, os mesmos autores fazem uma análise sobre uma das áreas que passou por vários projetos de 
intervenções municipais, com remoções e diversos conflitos envolvendo populações de "classe baixa", a exemplo da Vila Roriz, na área central:

A ocupação inicial do bairro ocorreu com o remanejamento dos moradores que habitavam as imediações da rede ferroviária há 30 anos, e que foram submetidas a um processo violento de desocupação por parte do poder público. Nesta área, hoje, localizam-se a Avenida Goiás Norte e o Terminal Rodoviário de Goiânia. (MOYSÉS e BERNARDES, 2003, p. 17)

A realidade da cidade é a seleção privilegiada de espaços, no qual o mercado imobiliário investe em novas centralidades, a exemplo do processo de verticalização na região sul de Goiânia, uma das áreas de maior densidade demográfica, com população concentrada de "classe média alta" e "classe alta" (MARTINS, 2014).

Passamos a tratar da configuração espacial de "espaços de maioria branca" com percentuais acima de $75 \%$ de população residente desse segmento e "espaços de maioria negra”, também com a mesma marca percentual desse conjunto racial.

\section{Espaços de maioria branca em Goiânia}

Gonzalez apontava nos anos 1980 a segregação racial e espacial nas cidades brasileiras, quando o IBGE voltava a incluir no Censo o dado cor/raça:

Os lugares naturais do grupo branco dominante são moradias amplas, espaçosas, situadas nos mais belos recantos da cidade [...] e devidamente protegidas por diferentes tipos de policiamento [...] até a polícia formalmente constituída. Desde a casa grande e do sobrado, aos edifícios e residências atuais, o critério tem sido o mesmo (GONZALEZ, 1982, p. 15).

Não vamos nos ater aos processos históricos. No entanto, consideramos que a variável racial pode e deve ser acrescentada para se pensar a segregação em Goiânia, como um princípio estruturante do espaço urbano, o que possibilita discutir o "racismo urbano", as barreiras e os limites de acesso desses espaços racial e socialmente hegemônicos.

A procura por locais vistos como seguros e de qualidade levou o mercado imobiliário a valorizar as novas centralidades na cidade. Grupos e indivíduos com poder econômico ("classe média alta" e "classe alta") escolhem os locais para se viver e, também, perto de quem morar, implicando em separações das classes e grupos sociais.

A forma de morar em condomínios fechados, horizontais ou verticais, intensifica ainda mais as diferenciações no espaço urbano e estabelece fronteiras sociais visíveis nas cidades brasileiras. Em Goiânia há uma demanda crescente de condomínios financiados pelo capital imobiliário nas regiões Leste e Norte da capital, produzindo espaços segregados de "classe média alta" e "classe alta":

Esses complexos residenciais urbanos proliferam na cidade de Goiânia. Aumentou sensivelmente o número de processos solicitando a aprovação de novos loteamentos de condomínios horizontais fechados, caracterizando um estilo novo no processo de desconcentração urbana da cidade. Essa nova forma 
de morar na cidade interfere na representação que seus habitantes têm dela. Os condomínios horizontais fechados passam a constituir "objeto de desejo" para um número considerável da população, apontando para um novo tipo de segregação espacial da cidade. (MOYSÉS e BERNARDES, 2003, p. 20)

$\mathrm{Na}$ procura por essas áreas, muito provavelmente a diferenciação racial não é evidenciada. No entanto, observamos a configuração de espaços de maioria branca, ou seja, bairros com porcentagem desse segmento acima de $75 \%$ para correlacionar a segregação urbana, residencial e econômica juntamente com a variável racial. Na figura 2 existe certa homogeneidade de ocupação nas áreas centrais e também nas regiões sul, sudeste e leste da capital, em bairros identificados com porcentagens elevadas de brancos em relação a negros.

Os bairros que estão na região sul da cidade, considerados como centralidades, são: Setor Oeste, Setor Marista, Setor Sul e Jardim Goiás. Marinho (2006) trata esses bairros da região Sul de Goiânia como áreas de maior valor em metros quadrados na capital e que "comportam a concentração dos investimentos públicos, de serviços e de camadas de elevado poder aquisitivo" (p. 113). Continua a autora:

[...] concentraram-se na Região Sul, como: a instalação da TELEGOIÁS (1962) e a construção do Shopping Center Flamboyant (1981), no Jardim Goiás, nas margens da BR-153; a construção do Shopping Bougainville (1990) no Setor Marista; do Goiânia Shopping (1991), no Setor Bueno; do Shopping Buena Vista (2003); a transferência da rede de comunicação Jaime Câmara do núcleo central para o Bairro da Serrinha (1980); a implantação dos parques de lazer Vaca Brava (Setor Bueno) e Areião (na divisa entre o Setor Marista e Pedro Ludovico) na década de 1990; e, para completar, a inauguração recente do Paço Municipal (2000) no Jardim Goiás, nas proximidades da BR-153. A Região Sul foi privilegiada em relação à implantação de infraestrutura na cidade (p.125).

Mais à frente, correlacionaremos renda e identificação racial para discorrer melhor acerca dessas regiões e bairros. Cabe destacar como a faixa de concentração na parte sudoeste, sul, centro e leste da cidade é uma área significativa que poderíamos considerar "espaço branco", no qual se localizam os bairros (setores) Oeste, Marista, Bueno, Jardim Goiás e Setor Central, em que o quantitativo populacional desse segmento representa mais de $92 \%$ do total que ali reside.

A região com menos bairros de maioria branca, em Goiânia, é a Noroeste, com apenas dois - Bandeirantes e São Domingos - o que, por outro lado, indica uma região com bairros de concentração negra da cidade. Com esse perfil, a região Sudoeste de Goiânia apresenta os bairros Granville, Celina Park e Eldorado, com condomínios fechados. De acordo com a autora, a região Sudoeste é alvo da expansão imobiliária que produz novas centralidades e nova dinâmica nas regiões circunvizinhas. A região central de Goiânia também apresenta diversos bairros com concentrações de brancos, acima de $75 \%$, sendo também áreas valorizadas. Campinas, Setor Coimbra e Setor Central são bairros que têm investimentos públicos e serviços que atendem à população que ali vive. Destaca-se que as pessoas residentes nesses bairros são de "classe média alta", ou seja, têm renda de 5 a 10 salários mínimos. Gomes reelabora esse quadro: 
Em Goiânia, [...] as camadas de baixo poder aquisitivo são impedidas de apropriarem a Área Central da cidade. Então, a alternativa é ocupar áreas relegadas e afastadas do Plano Original. Com o auspício do poder público, implantou-se na capital o modelo de crescimento periférico, em que os pobres permaneceriam às margens dos locais mais desenvolvidos. (GOMES, 2007, p. 49).

Essas áreas apresentam uma porcentagem baixa de população negra, exceto nos chamados “aglomerados subnormais”, Quebra Caixote e Emílio Póvoa, com porcentagens acima de $75 \%$ de populações, de cor/raça negros situados respectivamente nos setores Leste Universitário e Criméia Leste, como nos bairros Central, Setor Coimbra, Campinas, Setor Aeroporto e outros. Nas figuras 2 e 3 fizemos uma justaposição dos mapas de cor/ raça e de renda ${ }^{3}$ por bairros em Goiânia, com as classes econômicas definidas pelo IBGE (2010): "classe média alta" e "classe alta".

Esses bairros, a priori, são "espaços abertos” e podem abrigar grupos negros das classes médias, ao contrário dos espaços de maioria negra nos quais há alta concentração de pobres, como veremos adiante. A figura 4 apresenta a correlação entre os condomínios fechados e as altas concentrações de brancos (75\%). Estudos no campo da geografia urbana problematizam essas áreas como autossegregadas em termos de renda:

Os condomínios fechados comprovam que o crescimento das áreas residenciais de alta renda não ocorre nos locais aleatoriamente. Mesmo que seja na periferia de Goiânia, existe um planejamento, um arcabouço para sua implantação e permanência. O processo de segregação está presente nas formas e funções espaciais, na sua materialização e na própria distribuição socioespacial, pois o próprio tempo não é armazenável, assim a localização não é um critério econômico. (GOMES, 2007, p. 118).

Reiteramos que a porcentagem de $75 \%$ é generalizada por questões metodológicas da pesquisa, mas pontualmente, existem condomínios como Alphaville e Aldeia do Vale que têm acima de $92 \%$ de suas populações residentes de cor ou raça branca ${ }^{4}$. Martins, ao tratar o processo de autossegregação em Goiânia, deixa explícito que morar em condomínios fechados e em regiões periféricas da cidade é uma opção para a população de "classe alta" ou "classe média alta": "Diferentemente do que acontece com as classes mais baixas, que se restringem às áreas mais distantes da cidade por um impedimento econômico claro, o valor da terra, que é mais baixo em relação a outros espaços da cidade" (2014, p. 107).

3. Para os dados de renda foram utilizados os de "domicílios particulares com rendimento mensal domiciliar per capita em salários mínimos" (IBGE, 2010), que equivale às somas dos rendimentos de todos os moradores de um domicílio. O salário em reais para o ano da pesquisa estava em $\mathrm{R} \$ 510,00$ (quinhentos e dez reais). A classificação econômica foi feita a partir da divisão por classes do IBGE. http://www.sidra.ibge.gov.br/

4. É necessário dizer que esses dois condomínios não estão situados em áreas comerciais como as citadas para a região sul. 


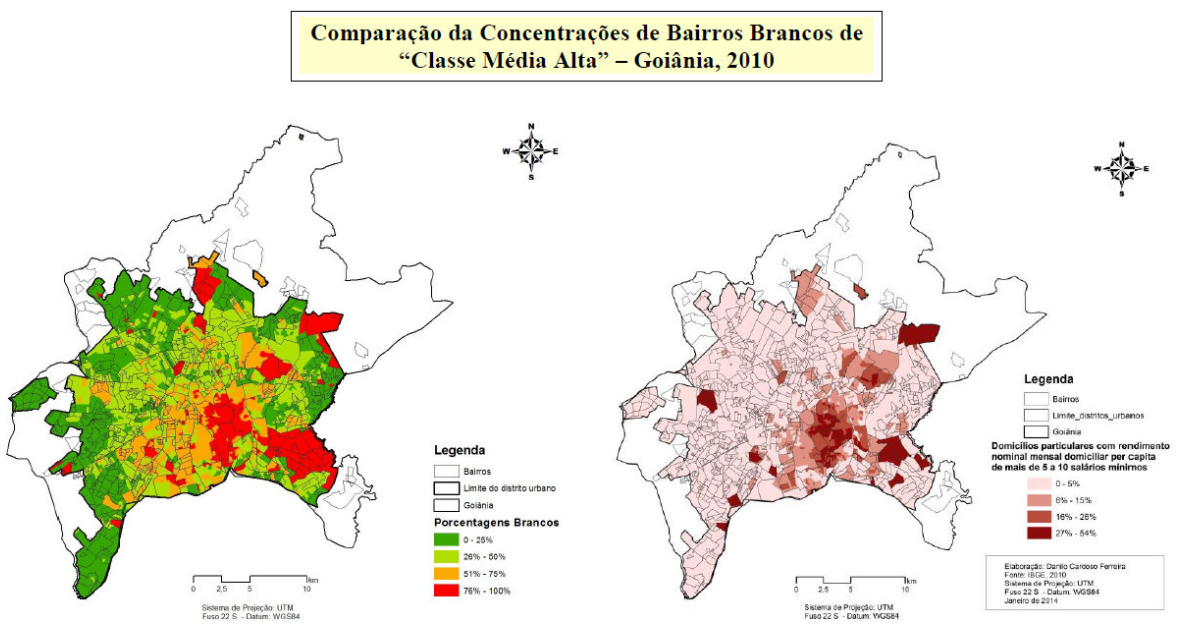

Figura 2. Justaposição das concentrações de brancos e da classe média alta por bairros. ${ }^{5}$

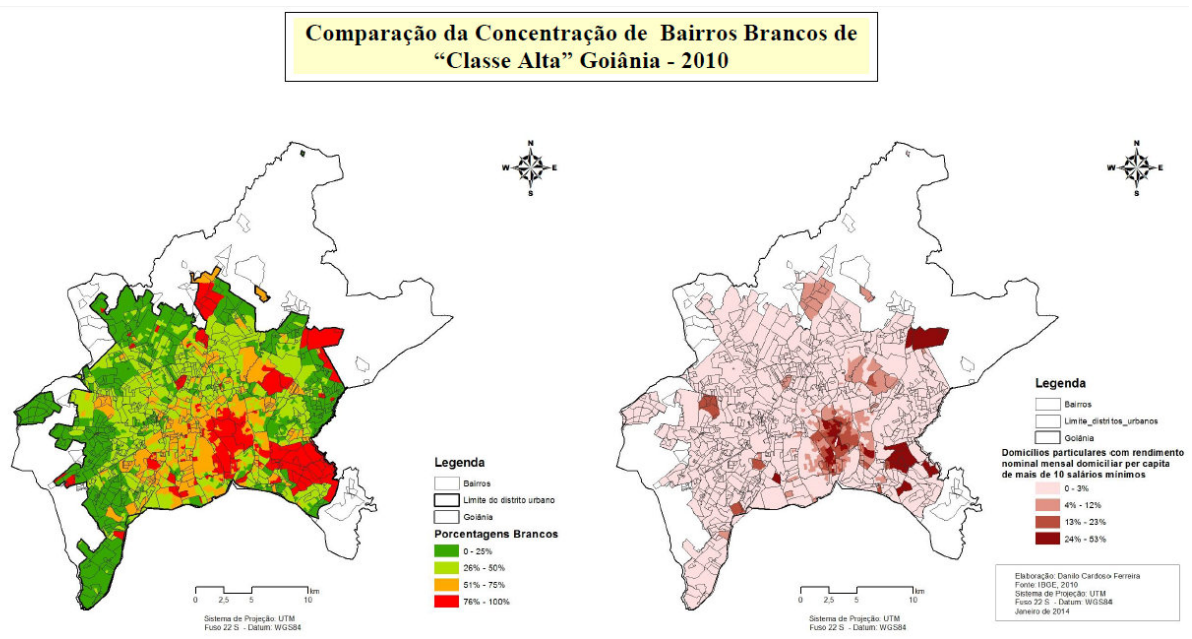

Figura 3. Justaposição das concentrações de brancos e da classe alta por bairros

5. Para a construção dos mapas de cor ou raça, optou-se por trabalhar com dados relativos, os quais permitem discernir quais distritos censitários possuem maior quantidade relativa (porcentagem) de brancos ou negros, por exemplo. Para o cálculo dos valores relativos, foi utilizada em ambiente SIG, a seguinte equação: \% relativa de brancos do distrito $=$ total de brancos do distrito x 100 /população total do distrito. 


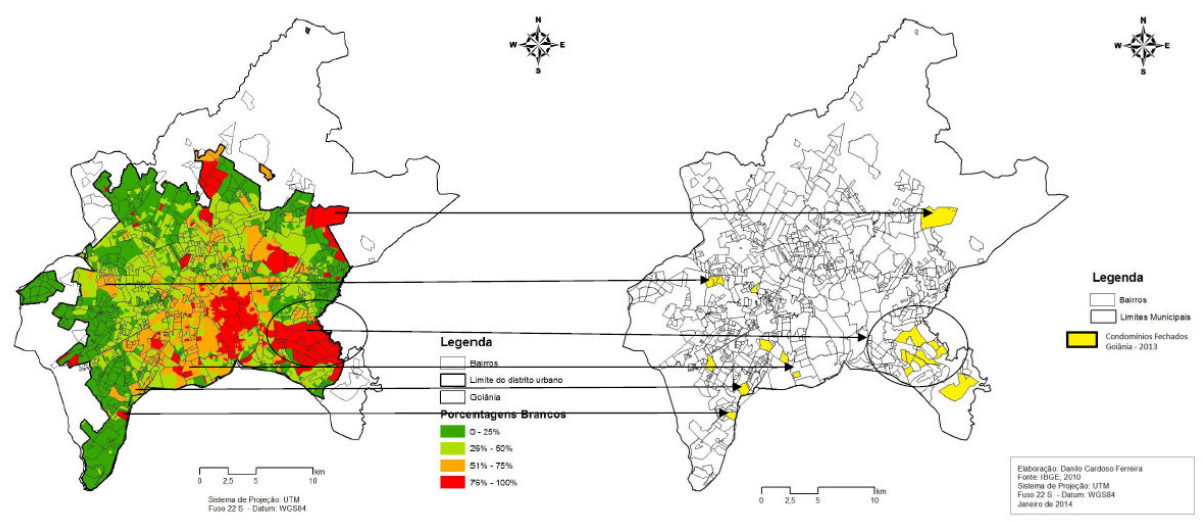

Figura 4. População Residente de Cor branca/E espacialização dos condomínios horizontais em Goiânia - 2010/2013.

Fonte: IBGE, Censo Demográfico, 2010; Divisão de Cadastro / DVCAD da SEMDUS, setembro de 2013.

\section{Espaços de maioria negra em Goiânia}

González (1982), com a qual abrimos a seção anterior, indica os lugares "de negros" nas cidades brasileiras:

Já o lugar natural do negro é o oposto, evidentemente: da senzala, às favelas, cortiços, porões, invasões, alagados e conjuntos "habitacionais" (cujos modelos são guetos dos países desenvolvidos) dos dias de hoje, o critério tem sido simetricamente o mesmo: a divisão racial do espaço (p. 15).

Os espaços negros cartografados para Goiânia são aqueles com porcentagens acima de $75 \%$ de população negra, não foge dos padrões apontados por autores como Campos (2006), para Rio de Janeiro; Garcia (2006) para as cidades de Salvador e Rio de Janeiro; e França (2010) para São Paulo. Esses estudos indicam que os espaços, territórios e lugares urbanos do segmento negro estão nas regiões periféricas, com baixa infraestrutura urbana e com problemas em relação aos seus domicílios, vivendo em áreas de risco e/ou em aglomerados subnormais.

Os territórios segregados socialmente e estudados por Moysés e Bernardes (2003), para Goiânia, correspondem em geral aos espaços de maioria negra. A região Noroeste é uma das principais, descrita como uma área de contrastes por Marinho (2006):

[...] A Região Noroeste tem sido apontada como subequipada e habitada pela população mais pobre dessa cidade, enquanto a Região Sul tem sido alvo da expansão das camadas de média e alta renda. Em síntese, em toda a cidade pode ser notada a presença de bairros habitados por camadas de baixa, média alta e alta renda, mas é, sem dúvida, entre as Regiões Noroeste, Central e Sul que existem os maiores contrastes [...] (p. 120). 
Nesta região se situam os bairros contíguos de Vila Mutirão I e II e Jardim Curitiba, nos quais outros(as) pesquisadores(as) localizaram expressões culturais e religiosas negras, a exemplo das religiões de matriz africana (TEIXEIRA, 2008) umbanda e candomblé - e das Festas da Senhora do Rosário e Congada (DAMASCENA, 2012). Estas observações indicam que a área pode ser considerada um território negro não pela relação demográfica, mas pelas identidades culturais, como apontou Rolnik (2009) para Rio de Janeiro e São Paulo.

As figuras 5, 6 e 7 justapõem os mapas de concentrações negras com as classes de renda "extremamente pobre", "baixa" e "média baixa". As localizações desses bairros se verificam comumente nas margens da metrópole, em residenciais ou conjuntos habitacionais, tais como na região Oeste, Noroeste e em alguns casos no centro de Goiânia.

Cabe destacar que os padrões de urbanização, nos bairros de maioria negra, estão diretamente associados a lugares com classe de baixa renda e com precárias condições de vida. Associadas a essas questões pode-se indicar as dificuldades de acessos dos moradores desses bairros ao se deslocarem para o trabalho e outras atividades, de cultura ou lazer, perdendo horas em terminais urbanos.

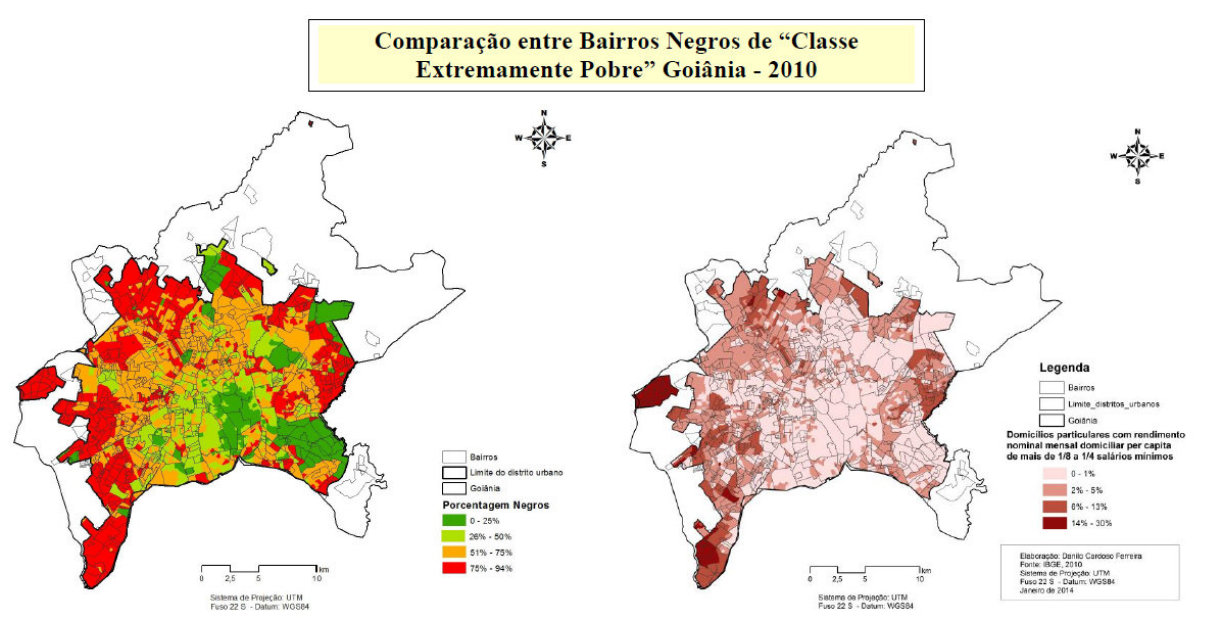

Figura 5. Justaposição dos Bairros Negros com os bairros de "Classe Extremamente Pobre".

Nos estudos feitos por Gomes (2005), o Assentamento Madre Germana II, na região sudoeste de Goiânia, é considerado um bairro segregado. Demonstra ainda que as pessoas que vivem neste bairro tem dificuldades de acesso à educação, saúde, infraestrutura urbana e saneamento básico. O autor, ainda, afirma:

6. Para a construção dos mapas de cor ou raça, optou-se por trabalhar com dados relativos, os quais permitem discernir quais distritos censitários possuem maior quantidade relativa (porcentagem) de brancos ou negros, por exemplo. Para o cálculo dos valores relativos, foi utilizado em ambiente SIG, a seguinte equação: \% relativa de negros do distrito $=$ total de negros do distrito x 100/população total do distrito. 
Em Goiânia, como vimos, as camadas de baixo poder aquisitivo são impedidas de apropriarem a Área Central da cidade. Então, a alternativa foi ocupar áreas relegadas e afastadas do Plano Original. Com auspício do poder público, implantou-se na capital o modelo de crescimento periférico, em que os pobres permaneceriam às margens dos locais mais desenvolvidos. (GOMES, 2005, p. 119).

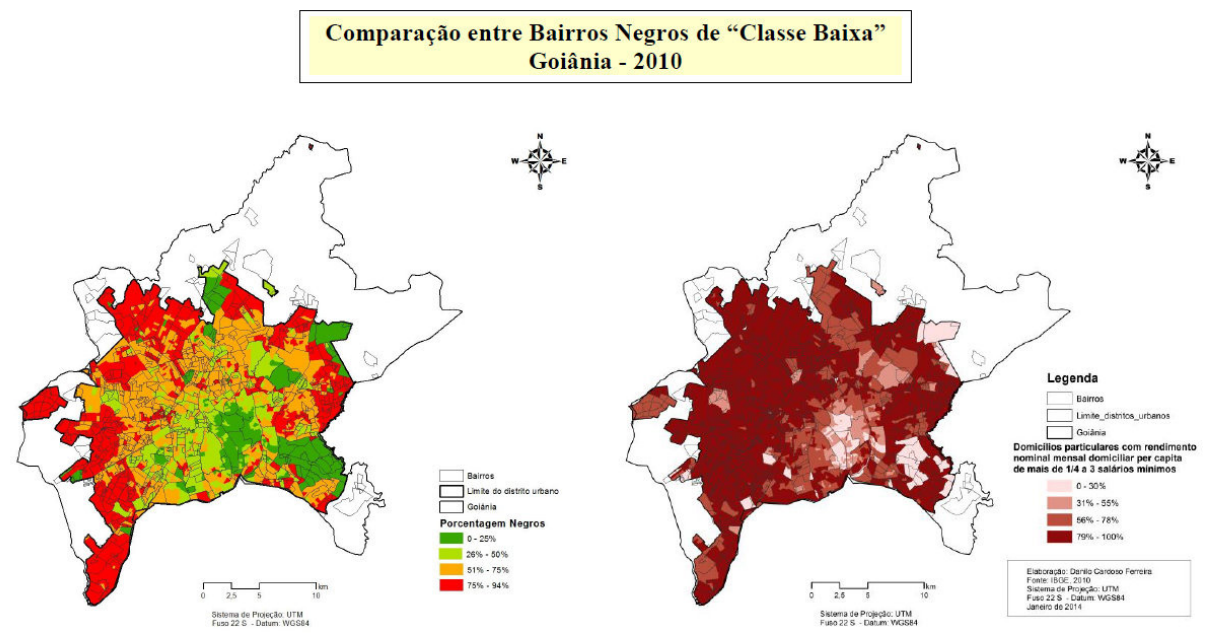

Figura 6. Justaposição dos bairros negros com os bairros de "classe baixa".

\section{Comparação dos Bairros Negros de "Classe Média} Baixa" Goiânia - 2010
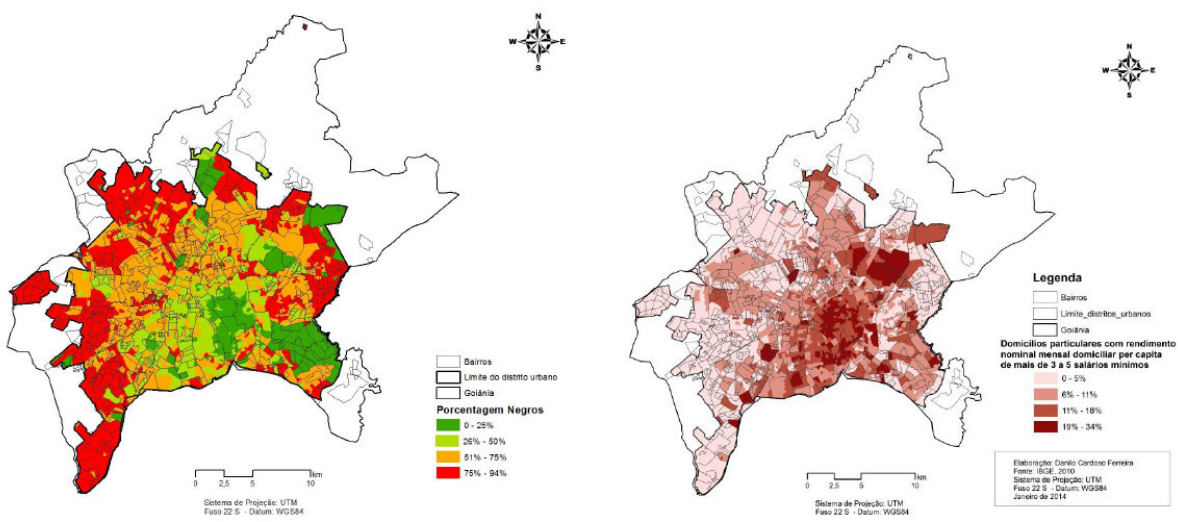

Figura 7. Justaposição entre dos bairros negros com os bairros de "classe média baixa" 
Os pobres, identificados pelo autor, da região sudoeste de Goiânia, mais especificamente os do bairro Madre Germana, são de um espaço ainda estigmatizado, periférico da capital, às margens da cidade. Espaço esse identificado ainda como espaço de populações de "classe extremamente pobre", "classe baixa" e também com as porcentagens acima de $75 \%$ de populações residentes negras.

Finsocial é um dos espaços negros com 17.183 habitantes, de classe extremamente pobre (figura 5), classe baixa, com domicílios que caracterizam as casas como autoconstruídas. Com mais de $75 \%$ de populações negras, esses bairros são estigmatizados pelos discursos da própria população e/ou da mídia goianiense como espaços violentos, perigosos para o convívio. Na região norte, o setor Vale dos Sonhos, um dos espaços negros, fundado na década de 1990 (GOIÂNIA, 2013), é um bairro que abriga as classes "sem rendimento", "extremamente pobre" e "baixa", e apresenta uma área de irregularidades de ocupação por questões ambientais, conforme diz a Secretaria do Meio Ambiente de Goiânia (MOYSÉS, 2005). Esse setor se situa muito próximo ao condomínio fechado horizontal Aldeia do Vale, cujos $75 \%$ da população é branca. Esse quadro indica a proximidade espacial dos grupos, mas, ao mesmo tempo, os distanciamentos sociais entre um espaço de "classe alta" e "branco" e um de "classe baixa" e "negro" (SILVA, 2008).

As áreas que foram identificadas por Moysés (2004), como segregadas, foram loteamentos clandestinos, irregulares, invasões e áreas de risco nas quais encontrou o número de aproximadamente $16,4 \%$ da população que viviam nesses territórios segregados. O autor ainda afirma que "A cidade é dividida em pedaços diferentes, multifacetada, torna-se mais visível quando se comparam as suas partes” (p. 200).

Os estudos feitos por Moysés colaboram para pensar e associar essa segregação em Goiânia com a variável racial, ao analisar que esses territórios cartografados pelo autor têm porcentagens maiores de populações negras (figura 5). Ao destacar os bairros segregados, tratados por outros(as) pesquisadores(as) como espaço de exclusão, também identificou-se os aglomerados subnormais em Goiânia como resultado da desigualdade social, econômica e com populações majoritariamente negra.

Os aglomerados subnormais, como apresentados pelo IBGE (2010), evidenciam a cidade de Goiânia vivendo em uma realidade diferente de estados como Rio de Janeiro e São Paulo, os quais possuem altos números de comunidades ou favelas ${ }^{7}$.

A capital goiana apresenta um dos maiores índices de desigualdades econômicas, que são também sociais e residencial, como apontado pelos nossos estudos. Fato que a realidade nos permite, mais uma vez, dizer que o processo de segregação socioespacial (MOYSÉS, 2009; MARTINS, 2014) também é de cunho racial. Não somente nos 7 (sete) pontos de aglomerados subnormais, mas em bairros negros com baixa infraestrutura urbana.

Os aglomeradas subnormais são considerados como invasão e também favelas; no caso o IBGE conceitualmente é conhecido como aglomerados subnormais, e a análise

7. Os aglomerados subnormais nas capitais paulista e carioca são os indicadores para a discussão de segregação e diferenciação social, econômica e residencial para autores como Campos (2006; 2012) e França (2010). 
que se faz é que até esses espaços pobres, em áreas de risco são irregulares, e que possuem uma porcentagem de negros maior do que a de brancos em Goiânia (IBGE, 2010).

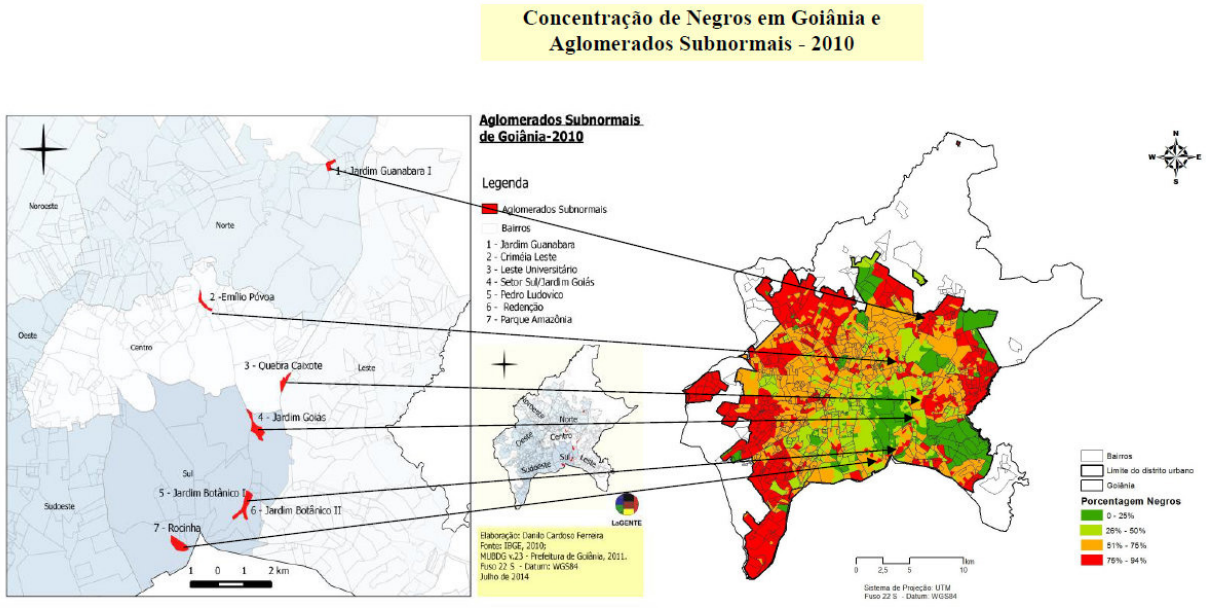

Figura 8. Justaposição dos Aglomerados Subnormais e concentração de Negros por Bairros, em Goiânia - 2010.

Esses espaços segregados, com populações de um grupo social e racial que se parecem, proporcionam a releitura da Geografia do corpo, dos indivíduos, da população, desses espaços que sofrem discriminação e também a falta de auxílio por parte dos poderes públicos.

A região com maior número de aglomerados subnormais (Região Sul) é também a com maior porcentagem de população branca e de população de classe "média alta" e "alta" (figura 8). A região que possui o menor número de bairros com populações negras, possui também o maior número de aglomerados subnormais que reproduzem a segregação residencial e racial.

\section{Diferenças e desigualdades sociais e raciais em Goiânia: algumas inferências}

No que diz respeito à relação entre as desigualdades econômicas e as raciais, precisamos destacar que, tanto em dados do IBGE (2010) quanto da ONU (2012) ${ }^{8}$, podemos observar discrepâncias sociais que podem ser inferidas à assimetrias entre brancos e negros em Goiânia. Essa diferença correlacionada com desigualdade precisa ser entendida não somente pela lógica socioeconômica, que em nosso entendimento apresenta limites, mas também pela perspectiva racial.

8. ONU - Habitat (2012). 
Em 2012, a ONU apontou que Goiânia é a cidade com maior índice de desigualdade econômica da América Latina, de acordo com o índice Gini, ${ }^{9}$ responsável por medir a desigualdade de renda, conforme indica o relatório do "Estado das cidades da América Latina e do Caribe 2012".

Em relação à média mensal salarial em Goiânia (figura 9), é 31\% maior que a renda mensal média do Brasil, 21\% maior que o índice para a região Centro-Oeste e $35 \%$ maior do que a renda média do Estado de Goiás. Isso indica que a capital goiana está entre as cidades de maiores rendas médias mensais do país, a exemplo de Brasília e São Paulo.

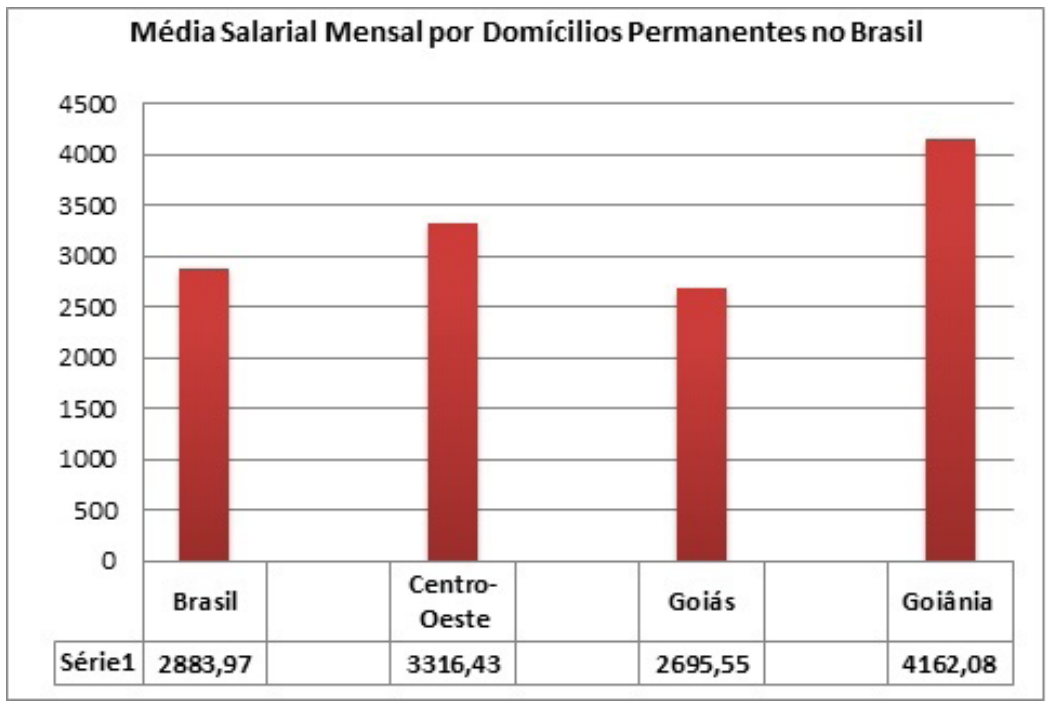

Figura 9. Rendimento mensal mediano dos domicílios particulares permanentes - Goiânia, 2010. Fonte: IBGE, Censo Demográfico, 2010.

A figura 10 traz os percentuais de classes de rendimento mensal por cor/raça para a Goiânia em 6 (seis) segmentos: "sem rendimento", "extremamente pobre”, "classe baixa", "classe média baixa", "classe média alta" e "classe alta", com foco em brancos e negros ("pretos" e "pardos"), ou seja, suprimindo as outras categorias.

Em Goiânia, as classes "média alta" e "classe alta" representam somente 11\% do total das pessoas residentes (somatório dos dois grupos raciais). Quanto à análise da renda, segundo cor e raça desses dois segmentos de maior renda, em Goiânia, 7,59\% são de brancos e $3,41 \%$ de negros.

As classes populares - "extremamente pobre", "baixa" e "média baixa" somam $58 \%$ do total da população (do somatório dos dois grupos raciais). Quanto à renda,

9. O Coeficiente de Gini é uma medida comumente utilizada para calcular a desigualdade de distribuição da renda; A mensuração de desigualdade de pobreza e riqueza. 
segundo cor ou raça, $17 \%$ desse grupo são de pessoas de cor ou raça branca e $71 \%$ são de pessoas negras. Essa assimetria é perceptível em grande parte da sociedade brasileira.

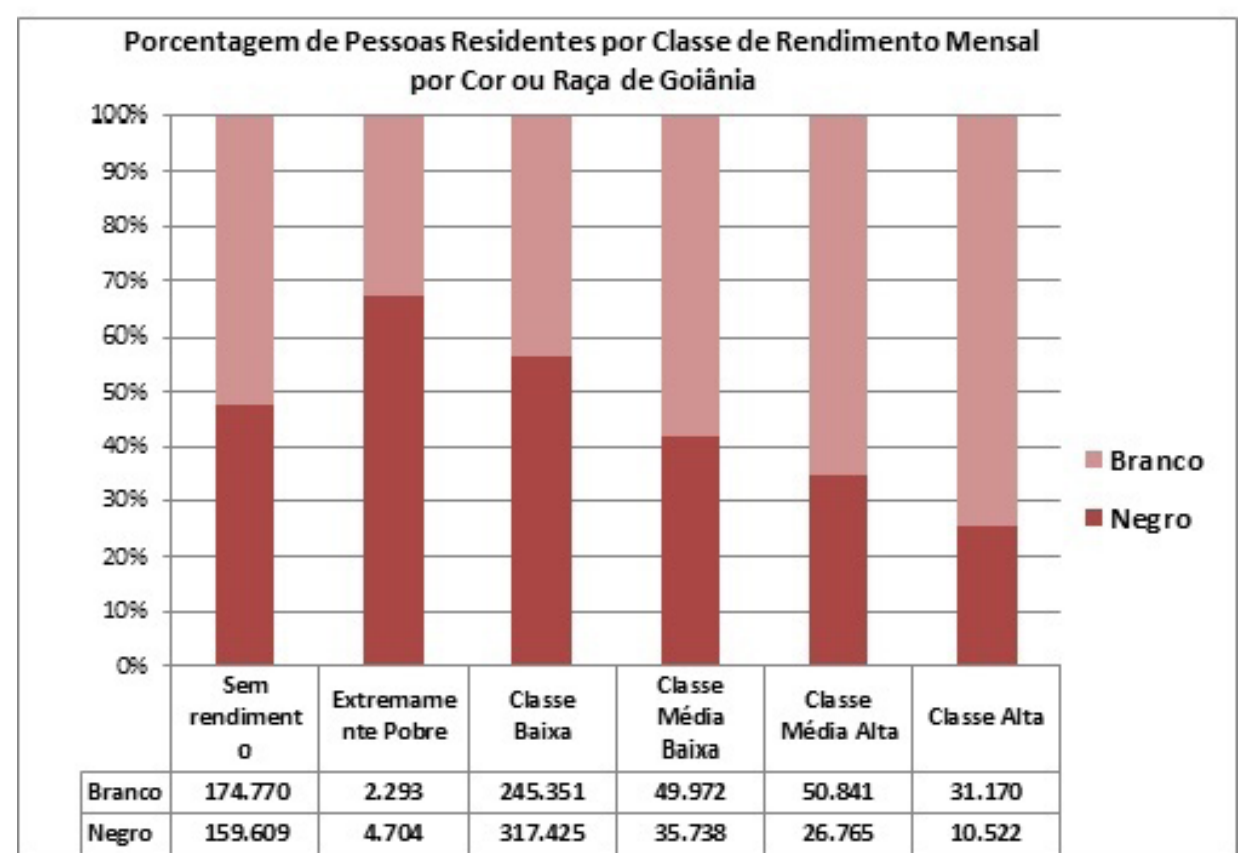

Figura 10. Percentual de classes de rendimento mensal por cor/raça em Goiânia 2010. Fonte: IBGE, Censo Demográfico, 2010

Merece destaque o fato de que $31 \%$ do total da população de brancos e negros em Goiânia vivem na faixa "sem rendimento" mensal. No tocante à identificação de cor ou raça nessa faixa, é o único caso em que visualizamos certa homogeneidade, dos 31\% total de domicílios sem rendimento mensal, 16\% são de grupos brancos identificados e $15 \%$ de negros.

\section{Considerações finais}

A Geografia que trata das questões raciais está em movimento político e dialético nas ciências humanas, pensando os sujeitos e suas espacialidades, nas relações sociais, nas diferenças e desigualdades no espaço, sobretudo urbano. Essa é uma abordagem que procura compreender a reprodução do espaço urbano a partir das contradições e dos conflitos sociais e espaciais, agregando dimensões culturais e de identidade racial.

Sabemos que a segregação no Brasil, segundo Negri (2008), é mais abordada pelo viés econômico e menos em termos étnico-raciais. O mesmo acontece com o processo de autossegregação das classes "média alta" e "alta". Os dados da identificação 
de cor ou raça e de renda, segundo os critérios do IBGE, estão na base dos mapas, tabelas e quadros, o que estruturou a pesquisa e levou a resultados que merecem alguns comentários.

A representação da cartografia racial contribuiu para colocar em pauta, mais uma vez, a importância dos mapas como linguagem de comunicação e de entendimento das contradições da sociedade e do espaço, particularmente do espaço urbano. Nesse sentido, compreender essas realidades "serve, antes de mais nada, para saber planejar o espaço para poder nele se organizar” (LACOSTE, 2001).

Um dos entendimentos finais desse trabalho é a compreensão de que havia um grande desafio a ser compreendido, porém, com o tempo de leituras e elaboração dos mapas, as reflexões teóricas e conceituais foram se tornando claras. Conclui-se que a diferenciação social produz a segregação como um fenômeno espacial. No caso específico desse trabalho, observou-se que, na sociedade brasileira, a diferenciação social, de base econômica, é também racial, particularmente a partir dos principais resultados obtidos para Goiânia, esses que se correlacionam ao que foi visto em outras grandes cidades brasileiras, como se pode ver na figura 11, a qual compara os mapas de "brancos" e "negros" em Goiânia.
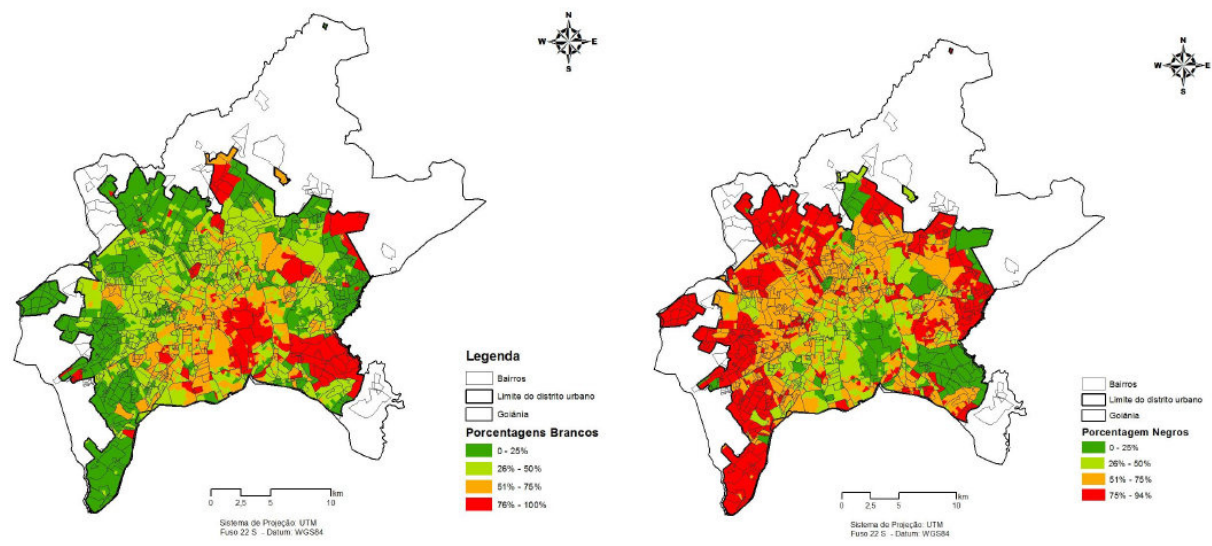

Figura 11. Justaposição dos mapas de cor ou raça Branco e Negro em Goiânia - 2010.

Goiânia é uma cidade desigual e segregada, conforme observamos por meio dos estudos de geógrafos(as) e sociólogos(as) que discorreram acerca de áreas residenciais, conjuntos habitacionais e condomínios fechados, sem acrescentarem a dimensão racial. Em contrapartida, espaços que vão desde a região noroeste, oeste, sem infraestrutura urbana, com grupos e populações de maioria negra nas regiões periféricas, ou no centro de Goiânia, como o caso dos aglomerados subnormais, Quebra Caixote e Emílio Póvoa. É importante destacar que existem populações brancas e pobres nesses bairros e que estamos ponderando como espaços segregados nessa capital. Mas o que nos chama a 
atenção é que nos espaços autossegregados e nos bairros considerados elitizados em Goiânia efetiva-se ou pequena presença da população negra.

Essa ausência ou baixa presença de negros nas áreas de população de "classe média alta" e "classe alta", com infraestrutura urbana, espaços considerados elitizados, com alto padrão de valorização (caso da Região Sul) e de maioria branca indica essa lógica da segregação socioespacial combinada com a questão racial nos leva a pensar que existem brancos nas regiões consideradas excluídas e segregadas. No entanto, a população negra está ausente ou tem baixo percentual nos espaços autossegregados na metrópole, a exemplo dos condomínios fechados da região Leste.

A cidadania em Goiânia também é "mutilada" (SANTOS, 1997) na localização residencial da maior parte do segmento negro, em áreas periféricas, implicando na lógica de circulação e deslocamento para o trabalho e para espaços educacionais formais. Os espaços negros estão em regiões periféricas, em conjuntos habitacionais, nas moradias improvisadas, nos aglomerados subnormais de Goiânia.

As desigualdades sociais, que também são raciais e se tornam espaciais, contribuem para a reprodução de espaços de grupos semelhantes. Nesse sentido, a cartografia acaba por representar a concentração da população negra e branca e os espaços de relativa coexistência. Os agentes hegemônicos da produção e reprodução do espaço, privado ou público, em geral não racializam seu discurso na valorização de determinadas áreas ou no planejamento, com exceção da publicidade de conjuntos residenciais para as classes médias altas e condomínios fechados que trazem corporeidades somente brancas.

Cabe lembrar Milton Santos, que ao ser questionado acerca de seu pertencimento racial, escreveu o texto "Ser negro no Brasil hoje", no qual finaliza apontando um percurso para descontruir o racismo nos olhares enviesados sobre o negro no Brasil.

\section{Referências}

ARRAIS, Tadeu Alencar. A produção do território goiano - economia, urbanização e metropolização. Goiânia: Editora da UFG, 2013.

CAMPOS,AndrelinodeOliveira.OPLANEJAMENTOURBANOEA "INVISIBILIDADE" DOS AFRODESCENDENTES: Discriminação étnico-racial, intervenção estatal $e$ segregação sócio-espacial na cidade do Rio de Janeiro. Tese apresentada ao Programa de Pós-Graduação em Geografia (PPGG) da Universidade Federal do Rio de Janeiro, 2006.

CASTILHO, Denis. Modernização territorial e redes técnicas em Goiás. Goiânia: Editora UFG, 2016.

CORRÊA, Roberto Lobato. O Espaço Urbano. São Paulo: Ática, 2002.

DAMASCENA, Adriane A. Os jovens, a congada e a cidade: percursos e identidades de jovens congadeiros em Goiânia. Tese de doutorado em Geografia. Goiânia, UFG, 2012.

FRANÇA, Danilo Sales do Nascimento. Raça, Classe e Segregação Residencial no Município de São Paulo. Dissertação apresentada ao Programa de Pós-Graduação em 
Sociologia da Faculdade de Filosofia, Letras e Ciências Humanas da Universidade de São Paulo, 2010.

GARCIA, Antônia dos Santos. DESIGUALDADES RACIAIS E SEGREGAÇÃO URBANA EM ANTIGAS CAPITAIS: Salvador, Cidade d'Oxum e Rio de Janeiro, Cidade de Ogum. Tese apresentada ao Curso de Doutorado do Programa de Pós-Graduação em Planejamento Urbano e Regional da Universidade Federal do Rio de Janeiro - UFRJ, 2006.

GOIÂNIA, Prefeitura Municipal. Plano Diretor de Goiânia. Disponível: http://www. goiania.go.gov.br/download/legislacao/PLANO_DIRETOR_DO_MUNICIPIO_DE_ GOIANIA_2007.pdf. Acesso: Janeiro, 2013.

GOMES, Rui Rocha. Goiânia Desigual e Segregadora. In: PAULA, Flávia Maria de Assis; CAVALCANTI, Lana de Souza (Org.). A cidade e seus Lugares. Goiânia: E.V., 2007. P. $29-52$.

GONZALEZ, Lélia. A mulher negra na sociedade brasileira. In: LUZ, Madel T. (Org.). $O$ lugar da mulher: estudos sobre a condiçção feminine na sociedade atual. Rio de Janeiro: Graal, p. 87 - 106.1982.

IBGE. Características Gerais da População. Censo Demográfico. Rio de Janeiro, p. 1-178, 2000. Disponível:

IBGE. Base de informações do Censo Demográfico 2010: Resultados do Universo por setor censitário. Rio de Janeiro, 2011. Disponível: http://www.censo2010.ibge.gov.br/ resultados. Acesso: Janeiro de 2013.

IBGE/SIDRA. Sistema IBGE de Recuperação de Recuperação Automática. Rio de Janeiro, 2010. http://www.sidra.ibge.gov.br/. Acesso: Janeiro de 2013.

MARINHO, Clorisnete Borges. Região Sul de Goiânia: um lugar valorizado na metrópole. GEOUSP - Espaço e Tempo, São Paulo, No 19, pg. 113 - 129, 2006.

MARTINS, Rubia Nara Silva. Geotecnologias aplicadas ao estudo de desigualdades socioespaciais no espaço intraurbano goianiense (1991 - 2010). Dissertação de Mestrado apresentada ao Programa de Pesquisa e Pós-graduação em Geografia do Instituto de Estudos Sócio-Ambientais, da Universidade Federal de Goiás, 2014.

MOYSÉS, Aristides e BERNARDES, Genilda D'arc. Segregação Urbana e Desigualdade Social em Goiânia: Estado, Mercada Imobiliária e Dinâmica Socioespacial. In: MOYSÉS, Aristides (org.). Cidade Segregação Urbana e Planejamento. Goiânia: UCG, 2005. P. 173-204.

MOYSÉS, Aristides; SILVA, Eduardo Rodrigues; BORGES, Elcileni de Melo; RIBEIRO, Marcelo Gomes Ribeiro. DA FORMAÇÃO URBANA AO EMPREENDEDORISMO IMOBILIÁRIO: a nova face da metrópole goianiense. Mercator - Revista de Geografia da UFC, ano 06, número 12, 2007. P. 37 - 50.

PAIXÃO, Marcelo. 500 anos de solidão: ensaios sobre as desigualdades raciais no Brasil. Curitiba: Appris, 2013. 
RATTS, Alex. Geografia, relações étnico-raciais e educação: a dimensão espacial das politicas de ações afirmativas no ensino. Terra Livre São Paulo/SP Ano 26, V.1, n. 34 p. 125-140 Jan-Jun./2010.

RIOS NETO, Eduardo e RIANI, Juliana de Lucena Ruas. Desigualdades raciais nas condições habitacionais na população urbana. In: SANTOS, Renato Emerson dos (Org.). Diversidade, espaço e relações raciais: O negro na geografia do Brasil. - 3. ed. - Belo Horizonte: Editora Gutenberg, 2009.

ROLNIK, Raquel. Territórios negros nas cidades brasileiras: etnicidade e cidade em São Paulo e Rio de Janeiro. In: SANTOS, Renato Emerson dos (Org.). Diversidade, espaço e relações raciais: O negro na geografia do Brasil. - 3. ed. - Belo Horizonte: Editora Gutenberg, 2009.

SANTOS, Milton. A Natureza do Espaço técnica e tempo razão e emoção. Editora da Universidade de São Paulo, 2008.

. Ser negro no Brasil hoje. Fonte: Folha de S.Paulo, Caderno Mais. 07 mai. 2000. Disponível em: $<$ http://acervo.folha.com.br/fsp/2000/05/07/72//581253 > Acesso em 30.08.2012.

SANTOS, Milton. Cidadanias mutiladas. In: CARDOSO, Ruth; KEHL, Maria Rita; BUCCI, Eugênio; DINES, Alberto; OLIVEIRA, Rosiska Darcy de; TELLES, Lygia Fagundes; PIÑON, Nélida; CHAUÍ, Marilena; DALLARI, Dalmo; SANTOS, Milton; KOVADLOFF, Santiago. O Preconceito. São Paulo: IMESP, 1996/1997. P . 33 - 44.

SANTOS, Renato Emerson dos. Sobre espacialidades das relações raciais: Raça, racialidade e racismo no espaço urbano. In: SANTOS, Renato Emerson dos (Org.). Questões urbanas e racismo. Petrópolis, RJ: DP et al,.; Brasília, DF: ABPN, 2012.

SILVA, Alessandro da. Entre Muros: Nós e Eles. Concepção, consolidação e interação entre o condomínio Aldeia do Vale e o Residencial Vale dos Sonhos entre 1998-2010. Disponível: http://pos.historia.ufg.br/up/113/o/19_Entre_Muros_N\%C3\%B3s_e_Eles. pdf. Acesso: Janeiro, 2013.

SOUZA, Marcelo Lopes de. Os conceitos fundamentais da pesquisa sócio-espacial. Rio de Janeiro: Bertrand Brasil, 2013.

TEIXEIRA, José Paulo. Paisagens religiosas no espaço urbano: espacialização das religiões cristãs e afro-brasileiras nos bairros Vila Mutirão e Jardim Liberdade em Goiânia, Goiás. Monografia de graduação em Geografia. Goiânia, IESA, 2008.

TELLES, Edward. Segregação residencial. In: . Racismo à brasileira: uma nova perspectiva sociológica. Rio de Janeiro: Relume-Dumará: Fundação Ford, 2003, p.161184.

VILLAÇA, F. Espaço Intra-Urbano no Brasil. São Paulo: Studio Nobel: FAPESP: Lincoln Institute, 2001. 
DANilo CARdoso Ferreira

Doutorando em Geografia pela Universidade Estadual de Campinas, Mestre em Geografia pela Universidade Federal de Goiás e Graduado em Geografia pela Universidade Estadual de Goiás. Atualmente é professor substituto da Universidade Estadual de Goiás - Câmpus de Itapuranga, do curso de Geografia. Endereço: Av. Rio Araguaia Esq. com Av. Paranaíba s/n $\mathrm{n}^{\mathrm{o}}$, Milton Camilo de Faria, Itapuranga-GO, CEP: 76.680.000.

E-mail: prof.daniloueg@gmail.com

\section{Alex Ratts}

Realizou estágio pós-doutoral em Geografia na Universidade Federal do Ceará. Possui doutorado em Antropologia pela Universidade de São Paulo, mestrado em Geografia pela Universidade de São Paulo e graduação em Arquitetura e Urbanismo pela Universidade Federal do Ceará. Atualmente é Professor do curso de Geografia da Universidade Federal de Goiás e atua junto ao Programa de PósGraduação em Geografia do Instituto de Estudos Sociambientais e do Programa de Pós-Graduação em Antropologia Social.

Endereço: Universidade Federal, Câmpus Samambaia (Câmpus II) CEP: 74001 970 - Caixa Postal: 131 - Goiânia.

E-mail: alex.ratts@uol.com.br

Recebido para publicação em novembro de 2016 Aprovado para publicação em março de 2017 